\author{
Alaksandr Dakukin \\ Homelski Państwowy Uniwersytet \\ im. F. Skaryny \\ https://orcid.org/0000-0001-8513-9535
}

DOI: $10.15290 /$ bb.2020.12.27

\title{
Да пытання аб мастацкім метадзе Алеся Разанава
}

Сёлета будзе адзначацца 50-годдзе выхаду першага зборніка Алеся Разанава - "Адраджэнне". За гэты час пісьменнік не толькі знайшоў для сябе адметны творчы шлях, але і стаў той асобай, якая аказала сапраўды неабсяжны па сваёй значнасці ўплыў на ўсё беларускае прыгожае пісьменства. Паэт-наватар і эксперыментатар, ён звяртаецца да сусветнага вопыту (ад нямецкамойнага канкрэтызму да ўсходніх філасофскіх плыняў), але праз разнастайныя жанры і тэматычнае багацце імкнецца паказаць найперш быццё беларуса (даўняе і сучаснае) як неад'емную частку быцця сусвету. Не перабольшаннем будзе адзначыць, што, не з'явіся у сярэдзіне мінулага стагоддзя зборнікі А. Разанава, беларуская літаратура магла б і не зведаць той усплеск цікавасці да медытатыўнай тэматыкі, пошукаў у галіне формы (хоку, графічная паэзія і інш.), перформансаў, што асабліва характэрны для літаратуры мяжы тысячагоддзяў.

Адпаведна, увесь гэты час робяцца спробы вызначэння і асэнсавання мастацкага метаду А. Разанава. Л. Молчан у гутарцы з пісьменнікам згадвае вядомыя словы А. Сідарэвіча, што А. Разанаў - сам школа і накірунак ${ }^{1}$. Сапраўды, разанаўская паэзія своеасаблівая, непадобная да астатняй, але найчасцей усё-такі вядзецца гаворка аб блізкасці поглядаў паэта да эстэтыкі альбо мадэрнізму, альбо постмадэрнізму.

1 А. Разанаў, Невядомая велічьня: гутаркі, артыкуль, згадкі, [б. м.] 2017, с. 44. 
Найбольш плённа гэтае пытанне было разгледжана Е. Лявонавай ${ }^{2}$. Навуковец абірае некалькі крытэрыяў, якія дастасойвае да разанаўскіх твораў і у выніку прыходзіць да наступнай высновы: Творчасчь Разанава сапраўды мае пункть судакранення з постмадэрнізмам (зрэштыл, а што з постмадэрнізмам не судакранаециа? I, нарэшче, з чьм не судакранаечча Разанаў?), аднак паспрабуем паказаць, што $i$ у пракрустава ложа постмадэрнізму творчасць гэтага пісьменніка не уัкладваециа, а па шэрагу сутнасных філасофска-эстэтычных параметраў яму нават супрачьстаіџь ${ }^{3}$ Значыць, на думку даследчыцы, беларускі паэт паводле сваіх мастацкіх поглядаў усё-такі больш блізкі да мадэрнізму.

Паспрабуем пашырыць і ўдакладніць характарыстыкі, прыведзеныя Е. Лявонавай; асаблівую ўвагу пры гэтым звернем на публіцыстыку пісьменніка (інтэрв'ю, артыкулы і інш.), а таксама мастацкія тэксты. Цікавасць у гэтым плане выклікае жанр зномаў, якія ўяўляюць сабой невялікія развагі-эсэ аўтара над пэўнымі пытаннямі, з'яўляюцца своеасаблівай паэтычнай філасофіяй. Паводле пісьменніка, назва жанру ўтварылася ад слова зно, пад якім трэба разумець мыслічельную рэчаіснасць ${ }^{4}$, якую ствараюць той, хто спазнае, $i$ тое, што спазнаеииа ${ }^{5}$. Дадамо таксама, што у 1990-я гады да газеты "Культура" выдаваўся дадатак "ЗНО”, у рэдкалегію якога ўваходзіў і А. Разанаў.

Пачнем 3 такой важнай характарыстыкі, як інтэртэкстуальнасць, то бок сувязь аднаго тэксту са шматлікімі іншымі. У шырокім сэнсе інтэртэкстуальнасць уключае разнастайныя алюзіі, рэмінісцэнцыі, прэцэдэнтныя імёны, запазычаныя сюжэты і г. д., што ўласціва любой творчасці. Калі мы паглядзім на тэксты А. Разанава, то ӱжо адразу $\breve{y}$ некаторых назвах пабачым адсылкі да пэўных гістарычных персанажаў і падзей: "Паганіні", "Тамаза Кампанела", “Арышт Кастуся Каліноўскага", "Сыны Іова", "Ганна-Марыя", "Усяслаў Чарадзей". У вершы "Пытанне" згадваецца Гамлет, які у роздуме ходзіць па двары палаца, а звычайная пячора (вершаказ "Пячора") нагадвае аўтару чэрап, у вачніцы якога якраз і будзе ўглядацца дацкі прынц. У творы "Папярэджанне" чытача сустракае маўклівая Прад-

2 Е.А. Лявонава, Агульнае $і$ адметнае, с. 166-174.

3 Тамсама, с. 166-167.

4 А. Разанаў, 3 апокрыфа ў канон: гутаркі, выступленні, нататкі, Мінск 2010, c. 72 .

5 А. Разанаў, Сума немагиьмасияў: зномь, Мінск 2009, с. 73. 
слава 6 і знакаміты крыж, створаны Лазарам Богшам. Галоўныя геpoi "Паэмы калодзежа" - Дзядал і Ікар - спрачаюцца аб неабходнасці палёту на самаробных крылах. Гаворачы ж пра касу, паэт у адпаведным вершаказе робіць адсылку да папулярнай песні і вобраза Кастуся Каліноўскага, калі адзначае, што вітаючьися з ёю, касу ксиічь касеи Ясь $i$ - развітваючыся з ёю - касінер Kaстусь ${ }^{7}$. Шмат знойдзем мы таксама зваротаў да біблейскіх сюжэтаў і вобразаў: гліна, з якой ствараецца ўсё і куды потым вяртаецца назад (паэма "Гліна", вершаказ "Гліна", версэт "Гліняныя чалавечкі"); маланка над Садомам і Гаморай (вершаказ "Маланка і гром"); райская даліна з кветкамі, што пояць салодкім нектарам, ды райскімі яблыкамі, што нясуць досвед (версэты "Падзел", "Паляванне у райскай даліне", “Дрэвы”); надзея на доўгачаканы прыход Збаўцы па хлеб надзённы і наддзённы (злёса "З-пад рукі"); нарэшце, паэма "Было балота" уззнаўляе ў чытацкай свядомасці Евангелле ад Яна, бо напачатку было балота 8 . Ёсць у пісьменніка і прыхаваныя адсылкі, якія цяжка заўважыць адразу. Так, злёса "Падмурак" цесна звязаная з купалаўскай паэмай "На Куццю" (якую А. Разанаў лічыць адным з самых актуальных для беларусаў тэкстам $\left.^{9}\right)$. Версэт "Танец 3 вужакамі" ўзыходзіць да старагрэцкіх міфаў пра Лаакоана або Персея і Андрамеду. Літаратуразнаўца I. Штэйнер адзначае асацыяцыі з кнігай Ф. Ніцшэ пра прарока Заратустру, якія ўзнікаюць пры чытанні "Паэмы рэха", "Першай паэмы шляху", а таксама шматлікіх версэтай ${ }^{10}$. Е. Лявонава праводзіць паралелі паміж разанаўскімі творамі і вершамі Р. М. Рыльке, асабліва тымі, што прысвечаны асэнсаванню сутнасці рэчаў (т. зв. традыцыя Ding-Gedicht - вершаў аб прадметах, рэчах $)^{11}$.

Інтэртэкстуальнасць з'яўляецца вельмі важнай прыкметай постмадэрнізму, але для яго галоўнае, па-першае, стварыць гіпертэкст, a, па-другое, высмеяць, спарадзіраваць з'явы папярэдняй культуры, прычым часта аўтар не вельмі дбае, каб паміж цытаванымі фрагментамі была трывалая сэнсавая сувязь. Тэкстаў такой гібрыдна-цытатнай прыроды мы $\ddot{y}$ А. Разанава не знойдзем. Адсутнічае ў яго і пост-

\footnotetext{
6 А. Разанаў, Танеи з вужакамі, Мінск 1999, с. 62.

7 Тамсама, с. 384.

8 Тамсама, с. 134.

9 А. Разанаў, Невядомая велічьня, с. 38.

10 І. Штэйнер, Уводзінь ў невьлоўнае: філасофія паэзіі Алеся Разанава, Мінск 2013, c. 265-273.

11 Е.А. Лявонава, Агульнае $i$ адметнае, с. 160-166.
} 
мадэрнісцкі “сіндром дэжавю". Наадварот, для творчасці пісьменніка характэрна новае "адкрыццё" існуючых аб'ектаў, якія узжо маюць вопыт неаднаразовага мастацкага аэнсавання і на ўзройні вобразнасці, i на ўзройні жанру. Напрыклад, А. Разанаў перастварыў на беларускую мову творы В. Хлебнікава, вынайшаўшы адметны жанр “3”. Таксама паэт актыўна звяртаецца да тэкстаў Францыска Скарыны, Кірыла Тураўскага, Сымона Буднага і інш., але не для таго, каб запазычыць пэўныя вобразы, сюжэты і іранічна пераасэнсаваць іх. Звяртаемся да папярэднікай: у іх глыбокія зместы - менавіта такія словы пісьменнік змясціў на форзацы кнігі "Маем найбольшае самі...", куды ўваходзяць пераствораныя А. Разанавым тэксты Ф. Скарыны, падчас прэзентацыі выдання у Гомельскім дзяржаўным універсітэце. На думку паэта, тэксты старабеларускай літаратуры цікавыя тым, што кожнае пакаленне людзей можа адкрыць у іх нешта новае, важнае менавіта для гэтай гістарычнай эпохі, паколькі агульны досвед змяняецца, а ўслед за ім адкрываюцца і новыя зместы, якія былі недаступнымі для папярэднікаў:

Першым быў Францішак Скарына, яго прадмовы і пасьляслоўі. Я чытаў і перачытваў, і нешта мяне не адпускала ад яго тэкстаў. I я думаў: у чым справа? Там нешта захоўвалася нявыказанае, невымоўнае, ня ўкладзенае да канца ў словы. Знайшой ключ - павярнуў яго, і прадмовы і пасьляслоўі Скарыны загаварылі як паэтычныя тэксты. Я іх ня выдумаў і вершы не наклаў на Скарынавы тэксты. Я проста здабыў іх адтуль, дзе яны знаходзіліся. Здабыў як самы сутны і існы голас ${ }^{12}$.

Таму пісьменнік імкнецца "ўвесці" даўнія творы у сучасны кантэкст, паглыбіць іхні змест, але пры гэтым ашчадна захаваўшы арыгінальнасць тэксту.

А. Разанаў звяртае ўвагу і на творчасць больш блізкіх да нашага часу пісьменнікаў: Янку Купалу, Якуба Коласа, Максіма Багдановіча, Анатолля Вярцінскага, Надзею Артымовіч, Зосю Сачко, Алеся Пісьмянкова і інш. Вынікам гэтай цікавасці сталі шматлікія літаратурна-крытычныя артыкулы ("Нататкі на дубовых лістах", "Жыта і васілёк", "Загадка дзвюх паралельных прамых", "Наступны, яшчэ не аб'яўлены, змест" і г. д.) і своеасаблівыя "водгукі" на пэўныя вершы ( "Дайсці да першага слова малітвы", "Безназойны верш Яна Чыквіна", "Зацемкі з зімовага саду", “Зацемкі з тэлефоннай будкі”). Аўтар адзначае:

12 А. Разанаў, Невядомая велічьня, с. 132. 
Ды у нас амаль уся спадчына непрачытаная, і нават тая (а можа, у першую чаргу тая), пра каго найбольш пісалася і гаварылася, - і Багушэвіч, і Купала, і Багдановіч. Нягледзячы на асобныя глыбокія распрацоўкі, як, напрыклад, "Загадка Багдановіча" Міхася Стральцова, пануюць "шыльдачкі" - хрэстаматыйныя стэрэатыпы, якія замінаюць бачыць і творцаў, і творы. Прачытаць твор - значыць увесці яго ў кантэкст сучаснасці, актуалізаваць... ${ }^{13}$.

Літаратурная спадчына, паводле пісьменніка, - каштоўны матэрыял для своеасаблівага "сумоўя" з мінулымі эпохамі, якое дапамагае нам лепей асэнсаваць сучаснасць і нават зазірнуць у будучыню, бо традьиъия - не толькі дылялог таго, што ёсиь, і таго, ито бьлло, але $i$ таго, што будз $e^{14}$ (вылучана А. Разанавым).

I для рамантызму, і для мадэрнізму, і для постмадэрнізму характэрная гульня, але $\ddot{y}$ апошнім яна выявілася найбольш яскрава. Праявы гульні можам назіраць, напрыклад, у вершаказах А. Разанава: аўтар абірае пэўную рэч (прадмет, з'яву надвор'я, абстрактнае паняцце і г. д., што выносіцца ў загаловак) і спрабуе вызначыць ейную сутнасць, абапіраючыся на гучанне слова. Так, жорны парожнія і жорсткія, яны кружацца і “жораюць" жмені зерня, перашароўваюць жытнюю жарству, каб атрымаўся корж ці піражок ${ }^{15}$; ліштва - лішак, які надае хаце пэўны кшталт і аблічча, клішэ з узораў лістоты і кветак, якое шануюць і $\breve{y}$ Літве, i $\ddot{y}$ Падляшшы ${ }^{16}$ i інш. Часта айтар карыстаецца звесткамі з розных моў (хлеб - Leben; малако - лакомство; муха - musų; певень - півень, петао, петел, petelin). Згадаем таксама Wortdichte - цікавы нямецкамоўны жанр, вынайдзены пісьменнікам. Дадзеную назву можна перакласці як "сцісласловы" альбо "вершасловы". Wortdichte шмат у чым вельмі блізкія да беларускамоўных вершаказай, але тут выкарыстойваюцца яшчэ малюнкі і разнастайныя графічныя сродкі: размяшчэнне тэксту адметным чынам, падкрэсліванне, вылучэнне шрыфтам (напрыклад, у вершасловах "Tunnel", "Sommer", "Kluft" і інш.). Заўважым, што аўтар не проста адвольна падбірае сугучныя словы, а насамрэч паказвае ўнутраную сутнасць пэўнай з'явы або прадмета i iх прызначэнне, бо з жорнаў сапраўды з'яўляецца жытняя мука, якой карыстаюцца для выпечкі каржой; гарох ахвотна ядуць, рохкаючы, свінні, ён грукаціць, нібы град, калі

13 А. Разанаў, 3 апокрыфба ў канон, с. 20.

14 А. Разанаў, Сума немагчьмасияў, с. 6.

15 А. Разанаў, Танеи з вужакамі, с. 435.

16 Тамсама, c. 62 . 
сыплецца з прыгоршчаў; скрынка, дзе "скрыты" скарб, сапраўды часта скрыпае і рыпіць, як скрыпка. У квантэмах таксама назіраем гульню, але, па словах паэта, яна перайтварае гукі ў гукасэнсы ${ }^{17}$. А. Разанаў не ставіцца цалкам адмойна да папулярнага ў сённяшніх маладых пісьменнікаў яўнага запазычвання 3 чужых тэкстай і далейшай гульні 3 радкамі, але папярэджвае, што тут варта прытрымлівацца меры. Хоць такія творы могуць быць цікавымі, займальнымі, але ӱжо з самага пачатку маюць першародны грэ $x^{18}$ - яны пазбаўлены арыгінальнасці, не адкрываюць новага. Акрамя таго, удзельнічаць у гульні можа толькі дасведчаны чытач, знаёмы 3 першакрыніцамі запазычаных фрагментаў, для іншага ж пэўныя часткі твора застануцца незаўважа-

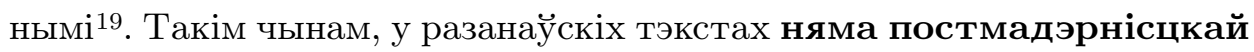
iроніi, яны вызначаюцца вельмі моцнай сур'ёзнасцю (падобнае мы можам бачыць таксама ў сімвалістаў). У адным са зномаў пісьменнік заўважае: Не, творчасчь не гульня, гэта такі “сур'ёз”, у параўнанні з якім само надзённае жыциё ўяўляециа гульнёю ${ }^{20}$.

3 адзначанага вышэй выцякае і такая асаблівасць творай беларускага паэта, як вялікая ӱвага да семантыкі, зместу тэкстаў. Для постмадэрнізму, наадварот, характэрна арыентацыя на прагматыку, перавага яе над семантыкай.

Хацелася б, канечне, сказаць, што тэксты А. Разанава будуць цікавыя кожнаму, бо разлічаны на асацыятыўнае мысленне чытача, заахвочваюць да суаўтарства і інш., але наш асабісты вопыт выкладання ў школе творчасці паэта (вывучаецца ў 11 класе) сведчыць аб яе разлічанасці на падрыхтаванага чытача, элітарнасці. Па-першае, нязвыклай для вучняй з'яўляецца адсутнасць рыфмы і традыцыйнага падзелу на строфы (у 10-11 класах адбываецца знаёмства, напрыклад, з верлібрамі Максіма Танка і вершамі у прозе Івана Тургенева, аднак аснойнае месца у школьнай праграме займаюць “традыцыйныя" вершы). Па-другое, цяжкасці выклікае значэнне пэўных слоў, пачынаючы ад самых простых (шыльдачка, замшэлы, суніцы, чарга, сутонне) і заканчваючы тымі адзінкамі, якія нават не кожны настаўнік здолее растлумачыць (вялебны, кадаўб, локшына, шуфель, кнайпа, лой і інш.). Намі быў праведзены шэраг ўрокаў у некалькіх адзінаццатых класах, прычым высветлілася, што ніводзін з вучняй да гэтага не ведаў нічога

17 А. Разанаў, 3 апокрыфа ў канон, с. 65.

18 А. Разанаў, Невядомая велічьия, с. 161.

19 Тамсама, с. 162.

20 А. Разанаў, Сума немагчымасияў, с. 59. 
пра асобу і творы А. Разанава. У канцы заняткаў у якасці рэфлексіі школьнікам было прапанавана пісьмова выказаць свае урражанні ад пройдзенага матэрыялу, намаляваць ілюстрацыі да тэкстаў і пад. Радуе, што большасць вучняў зацікавілася творчасцю пісьменніка, аднак былі і тыя, хто адзначыў, што сутыкнуўся з пэўнымі цяжкасцямі. Так, адна дзяўчына напісала пра “очень сложный стиль и непонятный для меня", іншыя казалі, што пройдзеныя на ўроках тэксты не выклікалі ніякіх асацыяцый і думак, не ўразілі.

Агульнай для мадэрнізму і постмадэрнізму з'яўляецца магчымасць поліварыянтнай трактойкі тэксту. У мадэрнізме (а дакладней, у сімвалізме) яна абумоўлена прыродай вобраза, які ўтрымлівае семантычнае ядро (знакавы аспект вобраза), што аднолькава ўспрымаецца ўсімі носьбітамі пэўнай культуры, зразумелае ўсім. Аднак вобраз дадаткова знаходзіцца пад уплывам тэксту і кантэксту, якія пашыраюць ягонае семантычнае напаўненне, таму і ўзнікае мнагазначнасць. Так, вобраз свечкі традыцыйна ўспрымаецца як сродак абароны ад нячыстай сілы, атрыбут разнастайных царкойных і народных абрадаў, варожбаў ${ }^{21}$. У версэце "Свечка" яна з'яўляецца яшчэ і сведчаннем пра чалавека, своеасаблівым адбіткам яго (і свечка, і чалавек нявечныя, але могуць гарэць: свечка полымем, а чалавек - агнём $\left.\partial y x y^{22}\right)$. У постмадэрнізме ж мнагазначнасць з'яўляецца вынікам множнасці ісціны.

Звернемся і да такой важнай рысы, як адносіны да хаосу. Пісьменнікі-постмадэрністы не лічаць яго варожым асяродкам для чалавека, значыць, пераадольваць хаос не трэба. Мадэрністы ж імкнуцца усё "прывесці да ладу". 3 хаосам змагаецца і лірычны герой шмат якіх тэкстаў А. Разанава. Так, у "Першай паэме шляху" распавядаецца пра чалавека, што крочыць па дарозе, каб разабрацца ў пытаннях, якія не даюць яму спакою: што знаходзіцца па-за панурымі гарадскімі мурамі, якой з'яўляецца тамтэйшая рэчаіснасць і (самае важнае пытанне) - кім ён, гэты чалавек, ёсць? Толькі пераадолеўшы разнастайныя выпрабаванні, герой атрымлівае доўгачаканыя адказы, прычым ў канцы паэма пераўтвараецца $\breve{y}$ апісанне сну ці трызнення апавядальніка (у тэксце губляецца сэнсавая сувязь паміж радкамі і знікаюць знакі прыпынку), што зноў жа адпавядае эстэтыцы мадэрнізму. У "Паэме жніва" мы бачым карціну ўсеабдымнага спусташэння і пакутаў (ці не адсылка гэта да Страшнага Суда?), выратавацца ад якіх можна толькі, калі

21 Беларуская міфалогія: энцыклапедычны слоўнік, Мінск 2004, с. 456.

22 А. Разанаў, Танеи з вужакамі, с. 398. 
ўслухацца ў голас Сэнсу, што гучыць з вышыняў і які здольны пачуць не кожны. "Падзел", "Мяжа", "Бязмежжа", "Маланка", "Расколіна", "Дубовы плот" - у гэтых вершаказах лірычны герой знаходзіцца у разгубленасці, бо прастора і час апынаюцца падзеленымі (на бажніцу світання і бажніцу змяркання, на мінулае і будучыню, рай і пекла, шлях "у свет" і “са свету", ад зямлі і да зямлі і інш.), а герой ніяк не наважыцца абраць той ці іншы бок. Такая ж праблема назіраецца у вершы Я. Купалы "Мужык", асэнсойваючы які А. Разанаў заўважае, што і першы бок (г. зн. свет забітасці, неадукаванасці, цяжкай працы), і другі (г. зн. свет панскі, "выкшталцоны") нясуць згубу, таму мужык застаецца на мяжы, дзе маецца трэці, выратавальны, шлях - унутр чалавека, углыб сябе 23 . Аднак іншы раз лірычны герой разанаўскіх вершаў усё-такі імкнецца злучыць назад гэтыя разрозненыя часткі, каб вярнуць ранейшую гармонію, хоць намаганні так і застаюцца марнымі (напрыклад, у злёсе "Разора").

Як вядома, пісьменнікі-мадэрністы актыўна асэнсойваюць уласны ўнутраны свет. Цікавасць да гэтай сферы выказвае і А. Разанай: Што там, у нас саміх, у гльбінях нашай свядомасиі: якія містэрыі адбььаючиа, якія рэкі иякуць, якія віры віруючь?.. Незразумелая патаемная сувязь паміж жыциём чалавека $i$ тымі глыбінямі, пра якія часам сведчаџь сны. I, магчыма, якраз у гэтым сакрэт мастакойскай самабытнасиі - каб характар творчасці адпавядаў характару тваіх сноั̆².

Варта спыніцца і на разуменні пісьменнікам ролі паэзіі і творчасці ӱвогуле. Паводле А. Разанава, вершы існуюць у сферы "невымоўнага", "безназоўнага", i, каб перанесці іх у наш свет, патрабуецца творца: Падазраю, што той верш, які пастукаўся ў душу паэта, які захацеў аб'явічиа, ужо існуе уั безназоўных сферах яго існасиі, напісань на безназоўнай мове. ШІто паэту застаеича, дык гэта ўвідавочніиь яго, агучьиь, "перакласиі" на сваю мову ${ }^{25}$. Трэба даць магчымасць вершу самому "адгукнуцца", прыйсці да паэта, бо творчасць - двухбаковы працэс, у якім задзейнічаны аўтар і твор. Да верша неабходна прыслухацца і зразумець, што ён хоча сказаць і як хоча ўвасобіцца у жыццё, бо, як заўважае пісьменнік, кожны верш - гэта адкрыццё, прычым адкрыццё абавязкова новага. Таму нельга імкнуцца да ме-

23 А. Разанаў, 3 апокрьфба ў канон, с. 31.

24 А. Разанаў, Сума немагчьмасияў, с. 32.

25 А. Разанаў, 3 апокрыфа ў канон, с. 21. 
ханічнага павелічэння колькасці тэкстай, варта дбаць пра іх якасць, пазбягаць імітацыі паэзіі:

Чым адрозніваецца імітацыя ад паэзіi? Паэтычны твор, па сутнасці, праходзіць увесь шлях развіцця - ад зерня да дрэва, ад клеткі да арганізму. У імітацы няма шляху. Імітатар падключаецца і праходзіць толькі нейкі уччастак шляху, робячы выгляд, што ішоў "усю дарогу". Што ж датычыць сапраўды творчай вучобы, то самая лепшая школа, у якой настаўнікі - не настаўнікі і вучні - не вучні і ў якой шануюцца не "завучаныя", а праяўленыя рысы - непаўторнасць і асабовасць ${ }^{26}$.

Згодна з А. Разанавым, растлумачыць і асэнсаваць, што такое паэзія, можна двума шляхамі. Першы - "культуралагічны" - звернуты у мінулае і абапіраецца на ўжо вядомае, напісанае, якое і атаясамлівае з паэзіяй. Другі ж шлях прадугледжвае, што вершы - гэта не паэзія, а спроба спасціжэння паэзіі (і каб як мага бліжэй наблізіцца да разумення паэзіі, трэба, каб гэтая спроба была шчырай, сапраўднай і ісціннай - шчырымі, сапраўднымі і г. д. павінны быць вершы) ${ }^{27}$. Таксама пісьменнік згадвае сувязь паэзіі з вышэйшым, Боскім пачаткам: Паэзія - прьєладная тэалогія: яна не вядзе гаворкі пра Бога, але ён

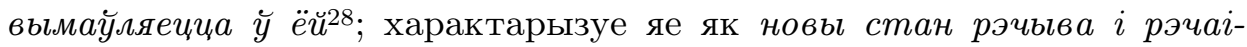
снасиi, мовы $i$ невылойнасиі ${ }^{29}$, называе хлебам наддзённым, асаблівай ведай. Тэургічная асаблівасць паэтычнага слова ў тылм, што яно вьнікае з гльбіні здзяйснення, і таму яно змяшчае ў сабе элемент дзеян$н^{30}$, таму калі ў вершы распавядаецца пра кветку, кветкай становіцца сама паэзія, калі апісваецца колер, гук, пах, то паэзія піша сапраўднымі колерам, гукам, пахам ${ }^{31}$.

Адпаведна, вельмі важная роля адводзіцца асобе творцы. Беларускі пісьменнік пагаджаецца з радкамі Я. Купалы (з ужо названай вышэй паэмы "На Куццю"), што паэт - гэта $i$ paб, $i$ иар 32 , слабы і моцны адначасова. Першая іпастась праяўляецца ў тым, што мастак падобны да прыроднага радовішча, якое належыць усім, таму павінен памятаць: (...) не марнуй, не рабуй, не крадзі...33. Аднак адначасова паэт

26 Tамсама, с. 24.

27 Тамсама, с. 25.

28 А. Разанаў, Сума немагчьмасияў, с. 82.

29 Тамсама, с. 12.

30 Тамсама, с. 99.

31 А. Разанаў, 3 апокрыфа ў канон, с. 23.

32 А. Разанаў, Сума немагчымасияў, с. 43.

33 Тамсама, с. 30. 
мае і вялікую ӱладу, ён - пункт адліку быция ${ }^{34}$, нават дэміург: I mym вылуัляеича дзіучная $i$ нават надзвычайная роля паэта: як ён скажа так $i$ атрымаециа, як ён зробіџь - так $i$ будзе, $і$ няма на зямлі вьшэйшай інстанцыі, якая перааспрэчыла б яго 35 . Паэта заўсёды павінен вабіць няпройдзены шлях, слова, якое яшчэ не было вымаўленае і нават зусім невымоўнае; прычым трэба памятаць, што праверку часам вытрымае не ўсё, напісанае на мове паэзіi, а толькі істотнае, ісціннае. Нягледзячы на важнасць аўтара, нельга забывацца і пра чытача: Сярод іншых відай мастачтва слоўнае мае найбольшую патрэбу ў сааўтары - y иытачыз ${ }^{36}$. Звязана гэта $з$ дыялагічнасцю паэзіі, таму ў прасторы верша чытач мае не менш правоў, чым аўтар 37 .

Безумоўна, у публіцыстыцы і зномах А. Разанава маюцца і іншыя цікавыя выказванні пра сутнасць мастацтва, характарызуюцца асаблівасці традыцыйнага і авангарднага, узаемасувязь зместу і формы і г. д.

Такім чынам, мастацкі свет А. Разанава з'яўляецца своеасаблівым і шматгранным. Можна пагадзіцца з высновамі Е. Лявонавай аб блізкасці эстэтычных поглядаў беларускага пісьменніка да мадэрнізму. В. Акудовіч нават заўважае: Калі трохі перабольшыць, то пэўна нават можна сказачь, што ўвесь наш мадэрн пачьънаеца $i$ канчаечиа творчасцю Разанава, прынамсі, беручь пад увагу перыяд да новай культурнай сітуачыі, якая пачала фармавачиа напрыканцы васьмідзесятых гадойз8. Тэксты паэта багатыя на адсылкі, прэцэдэнтныя імёны і пад., але не маюць гібрыдна-цытатнай прыроды; элементы гульні ўжываюцца не для іранічнага высмейвання з'яў папярэдняй культуры, а для паглыблення зместу твораў; пісьменнік з сур'ёзнасцю і адказнасцю ставіцца да Слова, падкрэслівае важнасць мастацтва у нашым жыцці. Відаць, кожны пагодзіцца, што А. Разанаў - яскравы наватар, вынаходнік адметных жанраў, які вывеў айчынную літаратуру на новы ўзровень. Ягоныя тэксты маюць невялікі памер, але з'яўляюцца вельмі змястойнымі, асацыятыўнымі і сугестыўнымі. Аднак паэт не адмяжоўваецца ад традыцыі, бачыць у ёй вытокі ўласнай творчасці: (...) з Купалам, дь $і$ ўвогуле з класікамі, я ад-

\footnotetext{
34 Тамсама, с. 47.

35 А. Разанаў, 3 апокрьфба ў канон, с. 54.

36 А. Разанай, Сума немагчьмасияў, с. 114.

37 А. Разанаў, 3 апокрыфа ў канон, с. 18.

38 В. Акудовіч, Уводзіны ў новую літаратурную сітуачыю, [online], https://knihi. com/storage/frahmenty/7akudovich.htm, [доступ: 18.02.2020].
} 
чуваю кройнае радство ${ }^{39}$, прычым 3 класікамі не толькі беларускімі. І. Штэйнер, Г. Кісліцына, Е. Лявонава і інш. літаразнаўцы бачаць $\breve{y}$ разанаўскай творчасці перагукі з Р. М. Рыльке, Г. Апалінэрам, І. Буніным, С. Малармэ і Ш. Бадлерам, філасофіяй Ф. Ніцшэ і М. Хайдэгера. Аднак нельга сцвярджаць, што пісьменнік ніяк не звязаны з сучаснымі з'явамі у літаратуры. Так, вялікую цікавасць выклікаюць мастацкія канцэпцыі і выставы, здзейсненыя паэтам разам з мастаком В. Маркаўцом: "Яйкаквадраты", “Збанабз”, "Ісвы”, "Функцыянальныя кантэксты", "Зместаформы”. Гэтыя выставы адначасова нагадваюць праекты авангардыстаў 1920-х гадоў і прадвяшчаюць перформансы бумбамлітаўцай. Найбольшую вядомасць набылі "Яйкаквадраты". А. Разанаў, гаворачы пра іх, звяртаецца да знакамітых "Квадратаў" К. Малевіча, якія былі "цяжарныя" новым вымярэннем, новай сутнасцю. "Яйкаквадраты" і аказаліся тым новым, той наступнасцю, што нарадзілася з малевічаўскіх твораў, узбагаціўшы і паглыбіўшы змест сваіх "бацькой". "Яйкаквадраты" ў сваю чаргу таксама "цяжарныя" новай рэчаіснасцю, якая пакуль не выявілася: Яньи ияжарныл сёмым "яйкаквадратам", які, відаџь, будзе $і$ прынцыпова адрознівачца ад увасобленьх шасці, $i$ з'яўляциа іхнім праиягам...40. Успомнім яшчэ цікавую літаратурна-музычную імпрэзу "I вынайшаў я крылы - вось яны...", што адбылася з удзелам А. Разанава і нямецкага кампазітара Ё. Г. фон Врохэма, які паклаў на музыку адну 3 паэм беларускага пісьменніка ${ }^{41}$.

Адзначым напрыканцы, што Г. Кісліцына - адзін з буйнейшых айчынных даследчыкаў постмадэрнізму (а таксама аўтар першай манаграфіі па творчасці А. Разанава) - аналізуючы асаблівасці сучаснай (на 2006 год) літаратуры ў працы "Новая літаратурная сітуацыя: змена культурнай парадыгмы”, не разглядае паэта як постмадэрніста, але згадвае, па-першае, што сённяшнія пісьменнікі актыўна звяртаюцца да філасофска-медытатыўнай тэматыкі, тады як у 1970-я гады яна была прадстаўлена найбольш яскрава толькі $\ddot{\mathrm{y}}$ аднаго Разанава. Па-другое, дзякуючы якраз А. Разанаву (і яго цікавасці да уссходняй філасофіi), у сучасную беларускую паэзію ўвайшла тэма смерці, прычым не $\ddot{y}$ фізіялагічным сваім аспекце, а як пераход з рэаль-

\footnotetext{
39 А. Разанаў, Невядомая велічьня, с. 3.

40 Тамсама, с. 56.

41 Е. Лявонава, Алесь Разанаў $i$ нямецкая літаратура, [y:] Літаратурная карта Еўропь: кантактыл, тылплогія, інтэртэкстуальнасць, Мінск 2012, с. 448.
} 
насиі быиия ў рэальнасць іншабыщия ${ }^{2}$. Адпаведна, А. Разанаў, будучы мадэрністам паводле ўспрыняцця свету і творчасці, паўплььваў на фармаванне найноўшага літаратурнага дыскурсу ${ }^{43}$, сваёй дзейнасцю падрыхтаваўшы беларускае слоўнае мастацтва да з'яўлення і пашырэння ў тым ліку і праяў постмадэрнісцкай эстэтыкі.

\section{I T E R A T U R A}

Akudovič V., Uvodziny ǔ novû̂ litaraturnû̂ situacŷu, [online], https://knihi.com/ storage/frahmenty/7akudovich.htm, [dostup: 18.02.2020] [Акудовіч В., Уводзіны ў новую літаратурную сітуацыюю, [online], https://knihi.com/sto rage/frahmenty/7akudovich.htm, [доступ: 18.02.2020].

Belaruskaâ mifalogiâ: èncyklapedyčny sloŭnik, Mìnsk 2004 [Беларуская міфалогія: эниыклапедыцины слоўнік, Мінск 2004].

Kìslìcyna G., Novâ̂ litaraturnaâ situacyâ: zmena kul'turnaj paradygmy, Mìnsk 2006 [Кісліцына Г., Новая літаратурная сітуачыл: змена культурнай парадыгмы, Мінск 2006].

Lâvonava E., Ales' Razanaǔ ì nâmeckâ̂ litaratura, [u:] Litaraturnaâ karta Eǔropy: kantakty, typalogiâ, intèrtèkstual'nasc', Mìnsk 2012 [Лявонава Е., Алесь Разанаў $i$ нямеикая літаратура, [y:] Літаратурная карта Еўропы: кантакты, тыпалогія, інтэртэкстуальнасиь, Мінск 2012].

Lâvonava E.A., Agul'nae i admetnae, Mìnsk 2003 [Лявонава Е.А., Агульнае і адметнае, Мінск 2003].

Razanaǔ A., Nevâdomaâ veličynâ: gutarkì, artykuly, zgadki, [b. m.] 2017 [Разанаў А., Невядомая велічыня: гутаркі, артыкульы, згадкі, [б. м.] 2017].

Razanaǔ A., Tanec z vužakami, Mìnsk 1999 [Разанаў A., Танеu з вужакамі, Мінск 1999].

Razanaǔ A., Z apokryfa ŭ kanon: gutarki, vystuplenni, natatki, Mìnsk 2010 [Paзанаў А., 3 апокрыфа ў канон: гутаркі, выступленні, нататкі, Мінск 2010].

Razanaǔ A., Suma nemagčymascâǔ: znomy, Mìnsk 2009 [Разанаў А., Сума немагчыммасияў: зномы, Мінск 2009].

Štèjner Ì., Uvodziny ǔ nevymoǔnae: filasofîa paèzìi Alesâ Razanava, Mìnsk 2013 [Штэйнер I., Уводзіны ў невымойнае: філасофія паэзіі Алеся Разанава, Мінск 2013].

42 Г. Кісліцына, Новая літаратурная сітуацыя: змена культурнай парадыгмьл, Мінск 2006, с. 166.

43 В. Акудовіч, Уводзіныл..., [доступ: 18.02.2020]. 


$$
\text { РЭ }
$$

\section{ДА ПЫТАННЯ АБ МАСТАЦКІМ МЕТАДЗЕ АЛЕСЯ РАЗАНАВА}

Артыкул прысвечаны асэнсаванню мастацкага метаду Алеся Разанава. Аналізуюцца творы, публіцыстыка паэта і робіцца выснова аб блізкасці ягоных эстэтычных поглядаў да мадэрнізму. Адзначаецца, што А. Разанаў - яскравы наватар, вынаходнік адметных жанраў, які вывеў беларускую літаратуру на сусветны ўзровень, аднак пры гэтым пісьменнік не адмяжоўвае сябе ад традыцыі, бачыць у ёй вытокі ўласнай творчасці. Тэксты паэта невялікія, але вельмі змястойныя, асацыятыўныя і сугестыўныя. Яны багатыя на адсылкі, прэцэдэнтныя імёны і пад., але не маюць гібрыдна-цытатнай прыроды; элементы гульні ўжываюцца не для іранічнага высмейвання з'яў папярэдняй культуры, а для паглыблення зместу творай; пісьменнік з сур'ёзнасцю і адказнасцю ставіцца да Слова, падкрэслівае важнасць мастацтва ў нашым жыцці.

Ключавыя словы: Алесь Разанаў, мастацкі метад, мадэрнізм, інтэртэкстуальнасць, жанр, асацыятыўнасць тэксту, культурная традыцыя.

\section{S T R E S Z C Z E N I E}

\section{O METODZIE TWÓRCZEJ ALESA RAZANAU}

W artykule omówiono twórczą metodę Alesa Razanau zastosowaną w jego utworach literackich i publicystyce. Autor arykułu formułuje wniosek, że twórczość A. Razanaua zbliża go do modernizmu. A. Razanau to bystry innowator i odkrywca nowych gatunków, dzięki któremu literatura białoruska osiągnęła światowy poziom. Jego teksty są krótkie lecz treściwe, assocjacyjne i sugestywne. Poeta nie odwraca się od tradycji, lecz widzi w niej źródła swojej twórczości. Teksty są bogate w odwołania, ale nie mają charakteru cytowań hybrydowych, elementy gry nie są stosowane, aby ośmieszyć zjawiska przeszłej kultury, lecz aby pogłębić wątki. Poeta traktuje słowo poważnie i z szacunkiem, podkreśla istotę sztuki w życiu człowieka.

Słowa kluczowe: Ales Razanau, metoda twórcza, modernizm, intertekstualność, gatunek, współczesna literatura białoruska, asocjatywność tekstu, tradycja.

\section{S U M M A R Y}

\section{ON THE CREATIVE METHOD OF ALES RAZANAU}

The article discusses the creative method of Ales Razanau. The poet's works and journalism are analyzed. The author has drawn the conclusion that A. Razanau is closer to modernism. He is a bright innovator, an inventor of new genres, thanks to whom Belarusian literature has reached world level. A. Razanau's texts are small, but very informative, associative and suggestive. The poet does not stand 
out against tradition, in which he sees the origins of his own work. Texts have many references, precedent names, etc., but they are not of hybrid-quotation nature; game elements are not used to ridicule ironically phenomena of the previous culture, but rather to deepen the content of works. The writer takes the Word with seriousness and responsibility, emphasizes the importance of art in our life.

Key words: Ales Razanau, artistic method, modernism, intertextuality, genre, contemporary Belarusian literature, text associativity, cultural tradition. 